\title{
The presence of lymphovascular and perineural infiltration after neoadjuvant therapy and oesophagectomy identifies patients at high risk for recurrence
}

\author{
S M Lagarde ${ }^{1}$, A W Phillips ${ }^{1}$, M Navidi ${ }^{1}$, B Disep ${ }^{1}$, A Immanuel ${ }^{1}$ and S M Griffin ${ }^{*}, 1$ \\ ${ }^{1}$ Northern Oesophago-Gastric Cancer Unit, Royal Victoria Infirmary, Queen Victoria Road, Newcastle-Upon-Tyne NE1 4LP, UK
}

Background: In patients treated for oesophageal cancer the importance of lymphovascular and perineural invasion (PNI) after neoadjuvant therapy has yet to be established. The aim of this study was to assess the incidence and prognostic significance of these factors in a consecutive series of patients with cancer of the oesophagus or gastro-oesophageal junction (GOJ) who underwent neoadjuvant therapy followed by oesophagectomy.

Methods: Clinical and pathology results from patients with potentially curable adenocarcinoma, or squamous cell carcinoma of the oesophagus or GOJ were reviewed. Patients were treated with neoadjuvant chemotherapy or chemoradiation followed by transthoracic oesophagectomy and two-field lymphadenectomy. The presence of venous invasion (VI), lymph vessel invasion (LI) and perineural invasion (PNI) were correlated with clinical outcomes.

Results: A total of 396 patients underwent oesophagectomy after neoadjuvant therapy for oesophageal cancer. Venous invasion was identified in 150 (38\%) of patients, LI in 203 (51\%) patients and PNI in 204 (52\%) patients. In all, 123 (31\%) patients had no evidence of either $\mathrm{VI}$, LI or PNI. A total of $96(24 \%)$ had a combination of two factors and 94 (24\%) had all three factors. The presence of $\mathrm{VI}, \mathrm{LI}$ and $\mathrm{PNI}$ was significantly related to tumour stage $(P=0.001)$. Median overall survival was 170.8 months when all three factors were absent, 44.0 months when one factor was present, 27.1 months when two factors were present and 16.0 months when all were present. Multivariate analyses revealed VI, LI and PNI or a combination of these factors were independent predictors of prognosis.

Conclusions: In oesophageal cancer patients treated with neoadjuvant therapy followed by oesophagectomy the presence of $\mathrm{Vl}$, $\mathrm{LI}$ and PNI has an important prognostic impact and may identify patients at high risk of recurrence who would benefit from adjuvant therapies.

Oesophageal cancer is an aggressive malignancy, with $\sim 450000$ new cases globally each year (Arnold et al, 2015). In patients with potentially curative disease treatment usually comprises neoadjuvant therapy followed by surgery. Neoadjuvant therapy improves radical resection rates (Kelsen et al, 1998), locoregional control (Langer et al, 2009; Bollschweiler et al, 2011) and treats distant micrometastases (Matsuyama et al, 2007). It has also been shown to increase survival in patients with locally advanced cancer (Medical Research Council Oesophageal Cancer Working Group, 2002; Cunningham et al, 2006; Van Heijl et al, 2008). Despite advances in neoadjuvant treatment, improved surgical technique and better patient selection, 5-year survival in these patients is still reported to range between 20 and 40\% (Sant et al, 2003; Lagarde et al, 2008). Presently, in the UK adjuvant treatment remains only 
in use for those patients with oesophagogastric junctional tumours treated using the MAGIC regime (Cunningham et al, 2006).

Currently, depth of tumour infiltration, and the presence and extent of lymph node metastases are the most important predictors of survival post surgery (Peyre et al, 2008). However, although patients who have no evidence of lymph node metastases after neoadjuvant therapy have a better survival, up to $40 \%$ go on to develop recurrent disease ( $\mathrm{Li}$ et al, 2007; Guo et al, 2014). Identification of other pathological features that may serve as indicators of poor outcome could permit increased accuracy in disease staging and consequently influence the use of adjuvant treatment.

The presence of venous invasion (VI), lymph vessel invasion (LI) and perineural invasion (PNI) have been increasingly identified as adverse prognostic markers in many malignancies (Liebig et al, 2009; Royston and Jackson, 2009; Cornwell et al, 2011; Chatterjee et al, 2012). PNI represents a pathological process whereby tumour cells infiltrate into the nerve sheath and may lead to local spread as well as distant dissemination (Liebig et al, 2009; D’Annoville et al, 2013). Lymphovascular invasion indicates the presence of tumour cells within the lumen of veins and lymphatics, and is associated with high levels of recurrence (Li et al, 2015).

Hitherto, there has been no study reviewing the impact of these factors in patients that have received neoadjuvant therapy in oesophageal cancer. The aim of this study was to assess the incidence and prognostic significance of these three factors in a consecutive series of patients with cancer of the oesophagus or gastro-oesophageal junction (GOJ) who underwent neoadjuvant therapy followed by transthoracic oesophagectomy with two-field lymphadenectomy.

\section{PATIENTS AND METHODS}

Patient population. A prospectively maintained database of all patients with adenocarcinoma or squamous cell carcinoma of the oesophagus or oesophageal junction was reviewed. All patients were discussed by the multidisciplinary team and those who received neoadjuvant chemo(radiation) therapy followed by oesophagectomy with two-field lymphadenectomy in the Royal Victoria Infirmary in Newcastle-Upon-Tyne between January 2000 and September 2013 were included.

Pretreatment staging. Initial staging comprised endoscopy with biopsy, endoscopic ultrasonography and a thoracoabdominal CT scan. A PET (CT) scan was not part of the initial staging, but was performed in some cases. Neoadjuvant treatment followed by oesophagectomy was indicated in patients deemed fit for surgery with histologically proven, locally advanced, resectable malignancy without distant metastases (cT1, N1-3, M0 or cT2-3, N0-3, M0) and/or had tumours of questionable resectability (cT4). Patients with metastases, unresectable tumours during exploratory surgery or macroscopically incomplete (palliative) resections (R2) and those who died in hospital after surgery were excluded. Current UICC TNM-7 was used to stage all patients Sobin et al, 2009).

Neoadjuvant treatment. Multiple neoadjuvant regimens were used in the present study, determined by the standard of care, and recruiting trials at the time of each patient's treatment. Nearly all patients received chemotherapy (98.5\%) compared with neoadjuvant chemoradiotherapy (1.5\%), which was principally radiotherapy with cisplatin and fluoruracil.

Of those having neoadjuvant chemotherapy the majority (388 patients) received cisplatin and fluorouracil (CF $-62.4 \%$ ) as per the OEO2 regimen (Allum et al, 2009) with 33\% receiving epirubicin, cisplatin and either fluorouracil or capecitabine (ECF (6 patients)/ECX (124 patients) - Magic regime (Cunningham et al, 2006)) and $1 \%$ received epirubicin, oxaliplatin and capecitabine (EOX) (Cunningham et al, 2008).

Neoadjuvant chemoradiation was used in only seven $(1.8 \%)$ patients, five received radiotherapy with carboplatin and paclitaxel, and the remaining two received other regimens.

Adjuvant ECC was planned in 100 (25.4\%) of patients and 71 received this treatment.

Transthoracic oesophagectomy with two-field lymphadenectomy was carried out 4-6 weeks after completion of neoadjuvant therapy using a conventional approach as previously reported (Griffin et al, 2002).

Histopathological analysis. Whilst in theatre specimens are resected en bloc and each lymph node station is dissected by the surgeon and submitted in a separate container to the pathology department. Surgical specimens were fixed for $24 \mathrm{~h}$ in $10 \%$ formalin before sectioning. At least four blocks with tumour and adjacent benign peri-tumoural tissue were selected for histopathological evaluation and immunohistochemical staining. When there was no evidence of residual macroscopic tumour, specimens were widely sampled.

Histopathological reporting was carried out by a team of specialist gastrointestinal pathologists and followed a standardised format in line with the current guidelines as produced by the Royal College of Pathologists (Mapstone, 2007): this included tumour type and differentiation, depth of tumour infiltration and degree of tumour regression as laid out by the Mandar criteria. Further, the number of nodes recovered, number of nodal metastases including the presence of extracapsular invasion and the presence of VI, PNI and LI were routinely recorded.

No specialised staining procedures were carried out to support the identification of lymphovascular infiltration.

Follow-up and definition of recurrence. All patients were followed until death or last follow-up (usually 10 years). All patients were seen at the outpatient clinic at 3- to 6-month intervals during the first 2 years, and every 6 months or annually thereafter. After 5 years, follow-up was on a yearly basis. Recurrence of disease was made on clinical grounds and confirmed either with CT scans or endoscopically.

Statistical analysis. Statistical calculations were performed by SPSS software, version 22.0 (SPSS, Chicago, IL, USA). To compare categorical data, the $\chi^{2}$ - or Fisher exact test was used. The Mann-Whitney $U$-test was used to compare continuous variables. Multivariate Cox-regression analysis was carried out to identify independent prognostic factors. All factors from the univariate analysis with a $P$-value $<0.10$ were entered in this multivariate analysis. $P$-values $<0.05$ (two-sided) were considered statistically significant.

\section{RESULTS}

Between January 2000 and September 2013, 425 patients underwent a transthoracic oesophagectomy after neoadjuvant therapy for mid-to-distal adenocarcinoma or squamous cell carcinoma of the oesophagus. In eight $(1.9 \%)$ patients preoperatively detected metastases or tumour in-growth led to a palliative resection. Two $(0.5 \%)$ patients underwent a salvage resection (after extended neoadjuvant therapy). Sixteen (3.8\%) patients died due to postoperative complications and these patients were excluded. In five (1.2\%) patients the presence (or absence) of either VI, LI and PNI or a combination was not reported in the pathology report and these patients were excluded.

Of the 394 included patients, almost $75 \%$ were male with a median age of $64(23-80)$ years. The tumour was located in the mid-oesophagus in $43(10.9 \%)$, in the distal oesophagus in 
$160(40.6 \%)$ and at the GOJ in 191 patients (48.5\%). The majority (302 patients, $76.6 \%$ ) had an adenocarcinoma. More than three quarters (346 patients, $87.8 \%$ ) had T3 tumours on EUS and only 37 patients $(9.4 \%)$ did not have suspicion on lymph node metastases (cN0) (Table 1).

After transthoracic resection with two-field lymph node dissection, pathological examination revealed that 389 patients $(98.0 \%)$ underwent a radical (R0) resection; microscopic tumour was left behind ( $\mathrm{R} 1$ resection) in the other eight patients $(2.0 \%)$ (Table 2). A median number of 33 (10-77) nodes was resected and identified. A total of 160 (40.6\%) patients had no evidence of lymph node metastases (ypN0). There were 234 (59.4\%) patients with positive nodes (ypN1-N3).

Venous invasion. The clinicopathological characteristics of the 245 (62\%) patients with no VI and 149 (38\%) patients with VI are summarised in Table 2. Significantly, VI was seen more frequently in patients who had more positive nodes resected $(P<0.001)$, a higher ypT stage $(P<0.001)$ or ypN stage $(P<0.001)$, and when lymph vessel $(P<0.001)$ or perineural invasion $(P<0.001)$ was present.

Lymph vessel invasion. The clinicopathological characteristics of the 193 (49\%) patients with no LI and 201 (51\%) patients with LI are summarised in Table 2. LI was seen more frequently in patients with adenocarcinomas $(P=0.002)$, more distal tumours $(P<0.001)$, in those who had more nodes $(P=0.003)$ and positive nodes resected $(P<0.001)$, a higher ypT stage $(P<0.001)$ or ypN stage $(P<0.001)$, and when venous invasion $(P<0.001)$ or perineural invasion $(P<0.001)$ was present.

\begin{tabular}{|c|c|c|}
\hline & $N$ & \\
\hline Number of patients & 394 & \\
\hline $\mathrm{Age}^{\mathrm{a}}$ & $64.0(23.37-79.85)$ & \\
\hline Male & $293(74.4 \%)$ & \\
\hline \multicolumn{3}{|l|}{ Histology } \\
\hline $\begin{array}{l}\text { Adenocarcinoma } \\
\text { Squamous cell }\end{array}$ & $\begin{array}{r}302(76.6 \%) \\
92(23.4 \%) \\
\end{array}$ & \\
\hline \multicolumn{3}{|l|}{ Tumour location } \\
\hline $\begin{array}{l}\text { Mid-oesophagus } \\
\text { Distal oesophagus } \\
\text { GOJ }\end{array}$ & $\begin{array}{r}43(10.9 \%) \\
160(40.6 \%) \\
191(48.5 \%)\end{array}$ & \\
\hline Radicality of surgery RO:R1 & 386 (98\%): 8 (2\%) & \\
\hline Number of resected nodes & $33(10-77)$ & \\
\hline Number of positive nodes & $1(0-35)$ & \\
\hline \multicolumn{3}{|c|}{ Pretreatment clinical T stage/post-treatment урТ } \\
\hline $\begin{array}{l}\text { cTx/ypT0 } 3(0.8 \%) \\
\text { cT1/ypT1 } \\
\text { cT2/ypT2 } \\
\text { cT3/ypT3 } \\
\text { cT4/ypT4 }\end{array}$ & $\begin{array}{c}17(4.3 \%) \\
3(0.8 \%) \\
21(5.3 \%) \\
346(87.8 \%) \\
21(5.3 \%) \\
\end{array}$ & $\begin{array}{c}48 \text { (12.2\%) } \\
75 \text { (19\%) } \\
238 \text { (60.4\%) } \\
16(4.1 \%)\end{array}$ \\
\hline \multicolumn{3}{|c|}{ Pretreatment clinical $\mathrm{N}$ stage/post-treatment ypN } \\
\hline $\begin{array}{l}\text { cN0/ypN0 } \\
\text { cN1/ypN1 } \\
\text { cN2/ypN2 } \\
\text { cN3/ypN3 } \\
\text { cNx }\end{array}$ & $\begin{array}{c}37(9.4 \%) \\
274(69.5 \%) \\
65(16.5 \%) \\
15(3.8 \%) \\
3(0.8 \%) \\
\end{array}$ & $\begin{array}{c}160(40.6 \%) \\
83(21.1 \%) \\
80(20.3 \%) \\
71(18 \%)\end{array}$ \\
\hline
\end{tabular}

Perineural invasion. The clinicopathological characteristics of the 191 (49\%) patients with no PNI and 201 (51\%) patients with PNI are summarised in Table 2. PNI was seen more frequently in patients with adenocarcinomas $(P<0.001)$, more distal tumours $(P=0.041)$, a higher cT stage $(P=0.033)$ as well as ypT stage $(P<0.001)$ or a higher $\mathrm{cN}$ stage $(P=0.034)$ as well as ypN $(P<0.001)$ stage and when venous invasion $(P<0.001)$ or perineural invasion $(P<0.001)$ was present.

A total of 123 (31\%) had no evidence of VI, LI or PNI. One out of three factors was present in 82 patients $(21 \%)$. A combination of two out of three factors was present in 96 (24\%), and 93 (24\%) had presence of all three factors. A higher total score was significantly related with adenocarcinomas, more distal tumours, in those more with positive nodes resected, a higher ypT stage as well as ypN stage. Interestingly it was not associated with the clinical $\mathrm{T}$ and $\mathrm{N}$ stages of disease.

Further, there was a strong correlation between the number of factors involved and a higher Mandard score $(R=0.539$, $P<0.001)$.

Survival analysis. Death irrespective of cause was regarded as a negative outcome in all cases. The Kaplan-Meier plots and results of the log-rank survival tests for the presence of one, two and three factors are shown in Figure 1 as well as the survival curves when each of VI, LI and PNI are present. These demonstrate that the median overall survival was 170.8 months (95\% confidence interval (CI): 68.9-272.8) if VI, LI and PNI were all absent. This fell to 40.9 months (95\% CI: 19.9-61.9) when one factor was present, 27.1 months (95\% CI: 22.8-31.4) when two factors were present and 16.3 months (95\% CI: 10.3-22.4) when VI, LI and PNI were all present. Univariate analyses revealed that the presence of VI, LI and PNI, or a combination of these factors together with female gender, histology type, a microscopically non-radical resection (R1), higher ypT stage and higher ypN stage, as significant prognostic indicators for survival (Table 3). Multivariate analyses demonstrated that among these the presence of VI, LI and PNI, or a combination of these factors, female gender, histology type, a microscopically non-radical resection, higher ypT stage and higher $\mathrm{ypN}$ stage were independent prognostic factors (Table 3 ).

Adjuvant treatment. Adjuvant chemotherapy was planned in only 100 patients, with 71 of them receiving at least once course of postoperative chemotherapy. The median survival in patients treated with postoperative ECX was 44.4 months (95\% CI: 27.6-61.1 months) in comparison with 18 months (95\% CI: 0-44 months) for those who did not receive postoperative chemotherapy $(P=0.072)$. Twenty-five patients had all three factors (VI, LI and $\mathrm{PNI}$ ) and those that received postoperative chemotherapy had a significantly better survival than those that did not (21.6 months CI: 5.5-37.6 vs 10.5 months CI: 7.2-13.7).

\section{DISCUSSION}

Cancer of the oesophagus or GOJ is an aggressive malignancy. Currently, $>50 \%$ of patients treated with neoadjuvant therapy followed by surgery have disease recurrence. The present study indicates that in patients treated with neoadjuvant therapy followed by a transthoracic oesophagectomy with two-field lymphadenectomy, the presence of VI, LI and PNI, individually and in particular in combination are associated with significantly worse survival.

Patients with cancer of the oesophagus or GOJ who undergo surgery are staged by the TNM staging system (American Joint Committee on Cancer (AJCC) and Union Internationale Contre le Cancer Sobin et al, 2009). The current UICC TNM-7 has acknowledged the importance of the number of involved nodes 
Table 2. Characteristics of patients and their histology in relation to the presence of each of $\mathrm{VI}, \mathrm{LI}$ and PNI

\begin{tabular}{|c|c|c|c|c|c|c|c|c|c|}
\hline & $\begin{array}{l}\text { VI not } \\
\text { present }\end{array}$ & $\begin{array}{c}\mathrm{VI} \\
\text { present }\end{array}$ & $P$-value & $\begin{array}{l}\text { LI not } \\
\text { present }\end{array}$ & LI present & $P$-value & $\begin{array}{l}\text { PNI not } \\
\text { present }\end{array}$ & $\begin{array}{c}\text { PNI } \\
\text { present }\end{array}$ & $P$-value \\
\hline Number of patients & $245(62.2 \%)$ & $149(37.8 \%)$ & & $193(49 \%)$ & $201(51 \%)$ & & $191(48.5 \%)$ & $203(51.5 \%)$ & \\
\hline Age & $63.5(23-79)$ & $65.3(33-80)$ & 0.165 & $64.22(34-79)$ & $64(23-80)$ & 0.165 & $64.3(23-79)$ & $63.9(33-80)$ & 0.286 \\
\hline Male & $179(61 \%)$ & $114(39 \%)$ & & $138(47.1 \%)$ & $155(52.9 \%)$ & & $140(47.8 \%)$ & $153(52.2 \%)$ & \\
\hline Female & $66(65.3 \%)$ & 35 (34.7\%) & 0.447 & $55(54.4 \%)$ & $46(45.6 \%)$ & 0.202 & $51(50.5 \%)$ & $50(49.5 \%)$ & 0.638 \\
\hline \multicolumn{10}{|l|}{ Histology } \\
\hline Adenocarcinoma & $183(60.6 \%)$ & $119(39.4 \%)$ & & $135(44.7 \%)$ & $167(55.3 \%)$ & & $133(44 \%)$ & $169(56 \%)$ & \\
\hline Squamous cell carcinoma & $62(67.4 \%)$ & $30(32.6 \%)$ & 0.239 & $58(63 \%)$ & 34 (37\%) & 0.002 & 58 (63\%) & $34(37 \%)$ & 0.001 \\
\hline \multicolumn{10}{|l|}{ Tumour location } \\
\hline Mid oesophagus & $29(67.4 \%)$ & $14(32.6 \%)$ & & $32(74.4 \%)$ & $11(25.6 \%)$ & & $27(62.8 \%)$ & $16(37.2 \%)$ & \\
\hline Lower oesophagus & 105 (65.6\%) & 55 (34.4\%) & & $86(53.8 \%)$ & 74 (46.2\%) & & $82(51.3 \%)$ & 78 (48.7\%) & \\
\hline GOJ & $111(58.1 \%)$ & 80 (41.9\%) & 0.265 & 75 (39.3\%) & $116(60.7 \%)$ & $<0.001$ & $82(42.9 \%)$ & $109(57.1 \%)$ & 0.041 \\
\hline \multicolumn{10}{|l|}{ Pretreatment T stage } \\
\hline T1 & $2(66.7 \%)$ & $1(33.3 \%)$ & & $2(66.7 \%)$ & $1(33.3 \%)$ & & $2(66.7 \%)$ & $1(33.3 \%)$ & \\
\hline $\mathrm{T} 2$ & $14(66.7 \%)$ & 7 (33.3\%) & & $13(61.9 \%)$ & 8 (38.1\%) & & 17 (81.0\%) & $4(19 \%)$ & \\
\hline T3 & 213 (61.6\%) & 133 (38.4\%) & & $168(48.6 \%)$ & 178 (51.4\%) & & 161 (45.2\%) & 185 (54.8\%) & \\
\hline T4 & $13(61.9 \%)$ & $8(38.1 \%)$ & & 7 (33.3\%) & $14(66.7 \%)$ & & $9(42.9 \%)$ & $12(57.1 \%)$ & \\
\hline$T x$ & $3(100 \%)$ & $0(0 \%)$ & 0.72 & 3 (100\%) & $0(0 \%)$ & 0.137 & $2(66.7 \%)$ & 1 (33.3\%) & 0.033 \\
\hline \multicolumn{10}{|l|}{ Pretreatment N Stage } \\
\hline No & $25(67.6 \%)$ & $12(32.4 \%)$ & & $17(45.9 \%)$ & $20(54.1 \%)$ & & $11(29.7 \%)$ & $26(70.3 \%)$ & \\
\hline N1 & 171 (62.4\%) & $103(37.6 \%)$ & & 129 (47.1\%) & 145 (52.9\%) & & 132 (48.2\%) & $142(51.8 \%)$ & \\
\hline N2 & $39(60 \%)$ & $26(40 \%)$ & & $35(53.8 \%)$ & $30(46.2 \%)$ & & 37 (56.9\%) & $28(43.1 \%)$ & \\
\hline N3 & $8(53.3 \%)$ & 7 (46.7\%) & & $10(66.7 \%)$ & 5 (33.3\%) & & $8(53.3 \%)$ & 7 (46.7\%) & \\
\hline $\mathrm{Nx}$ & $2(66.7 \%)$ & $1(33.3 \%)$ & 0.891 & $2(66.7 \%)$ & $1(33.3)$ & 0.493 & $3(100 \%)$ & $0(0 \%)$ & 0.034 \\
\hline \multicolumn{10}{|l|}{ Radicality } \\
\hline RO & $240(62.2 \%)$ & $146(37.8 \%)$ & & $189(49 \%)$ & $197(51 \%)$ & & $189(49 \%)$ & $197(51 \%)$ & \\
\hline R1 & $5(62.5 \%)$ & $3(37.5 \%)$ & 0.985 & $4(50 \%)$ & $4(50 \%)$ & 1 & $2(25 \%)$ & $6(75 \%)$ & 1 \\
\hline Number of resected nodes & $33(11-77)$ & $32(10-64)$ & 0.787 & $31(11-77)$ & $35(10-75)$ & 0.003 & $32(22-77)$ & $33(10-72)$ & 0.532 \\
\hline Number of positive nodes & $0(0-13)$ & $3(0-35)$ & $<0.001$ & $0(0-12)$ & $3(0.35)$ & $<0.001$ & $0(0-18)$ & $3(0-35)$ & 0.532 \\
\hline \multicolumn{10}{|l|}{ Post-treatment T stage } \\
\hline урT0 & 17 (100\%) & $0(0 \%)$ & & $17(100 \%)$ & $0(0 \%)$ & & $17(100 \%)$ & $0(0 \%)$ & \\
\hline урT1 & 41 (85.4\%) & $7(14.6 \%)$ & & 40 (83.3\%) & $8(16.7 \%)$ & & 47 (97.9\%) & $1(2.1 \%)$ & \\
\hline урт2 & 55 (73.3\%) & $20(26.7 \%)$ & & $41(54.7 \%)$ & $34(45.3 \%)$ & & 55 (73.3\%) & $20(26.7 \%)$ & \\
\hline урТ3 & 128 (53.8\%) & $110(46.2 \%)$ & & $90(37.8 \%)$ & $148(62.2 \%)$ & & $71(29.8 \%)$ & $167(70.2 \%)$ & \\
\hline урT4 & $4(25 \%)$ & $12(75 \%)$ & $<0.001$ & $5(31.3 \%)$ & $11(68.7 \%)$ & $<0.001$ & $1(6.3 \%)$ & 15 (93.7\%) & $<0.001$ \\
\hline \multicolumn{10}{|l|}{ Post-treatment $\mathrm{N}$ stage } \\
\hline ypNo & $131(81.9 \%)$ & $29(18.1 \%)$ & & 119 (74.4\%) & $41(25.6 \%)$ & & $116(72.5 \%)$ & $44(27.5 \%)$ & \\
\hline ypN1 & 54 (65.1\%) & 29 (34.9\%) & & 43 (51.8\%) & 40 (48.2\%) & & 42 (50.6\%) & 41 (49.4\%) & \\
\hline ypN2 & $36(45 \%)$ & 44 (55\%) & & 21 (26.3\%) & 59 (73.7\%) & & 24 (30\%) & 56 (70\%) & \\
\hline ypN3 & 24 (33.8\%) & 47 (66.2\%) & $<0.001$ & $10(14.1 \%)$ & 61 (85.9\%) & $<0.001$ & 9 (12.7\%) & 62 (87.3\%) & $<0.001$ \\
\hline LI present & 83 (41.3\%) & 118 (58.7\%) & $<0.001$ & NA & NA & & 54 (26.9\%) & 147 (73.3\%) & $<0.001$ \\
\hline PNI present & 93 (45.8\%) & $110(54.2 \%)$ & $<0.001$ & $56(27.6 \%)$ & $147(82.4 \%)$ & $<0.001$ & NA & NA & \\
\hline $\mathrm{VI}$ present & NA & NA & & 31 (20.8\%) & 118 (79.2\%) & $<0.001$ & 39 (26.2\%) & 110 (73.8\%) & $<0.001$ \\
\hline
\end{tabular}

by revising the $\mathrm{N}$ category from site-dependent staging to a numerically based classification ranging from N0 to N3.

In addition to these factors, the presence of VI, LI and or PNI in the tumour seems to be a surrogate for aggressive tumour behaviour and may serve as criteria for selecting patients for adjuvant therapy. Interestingly, the present study showed a survival benefit for those who had VI, LI and PNI and received postoperative chemotherapy according to the MAGIC protocol. Whilst this may be related to the chemotherapy received, it is possible that the improved survival may reflect a self-selecting group of patients who were better able to tolerate the additional treatment. Further studies looking are required, which focus on the value of adjuvant treatment in these high-risk patients. It is possible that the presence of VI, LI and or PNI may be used to stratify patient populations in future studies assessing the efficacy of adjuvant regimens. These factors may potentially have a preoperative prognostic use with assessment of these factors from endoscopic mucosal resection biopsies (EMR) potentially used to influence patient treatment (Eguchi et al, 2006). Venous invasion, $\mathrm{LI}$ and PNI were not related to preoperative $\mathrm{T}$ and $\mathrm{N}$ staging, however, with all factors there was a strong relationship with higher ypT and ypN stages. Whilst this suggests a relationship with disease downstaging, particularly with regards to the Mandard scores, this needs further investigation. Davies et al (2014) demonstrated that staging after neoadjuvant treatment, rather than clinical staging determine survival in this cohort of patients. The results from this study suggest that assessing preoperative assessment of VI, LI and PNI on biopsies may help improve clinical staging, although future studies are required to see whether adequate assessment of these factors is possible on such biopsies.

The incidence of VI, LI and PNI is not well reported, which may be due to whether or not these factors were actively sought. Tachezy et al (2014) recently reported an incidence of $13 \%$ for VI, $5 \%$ for PNI and $35 \%$ for LI in a cohort who underwent 

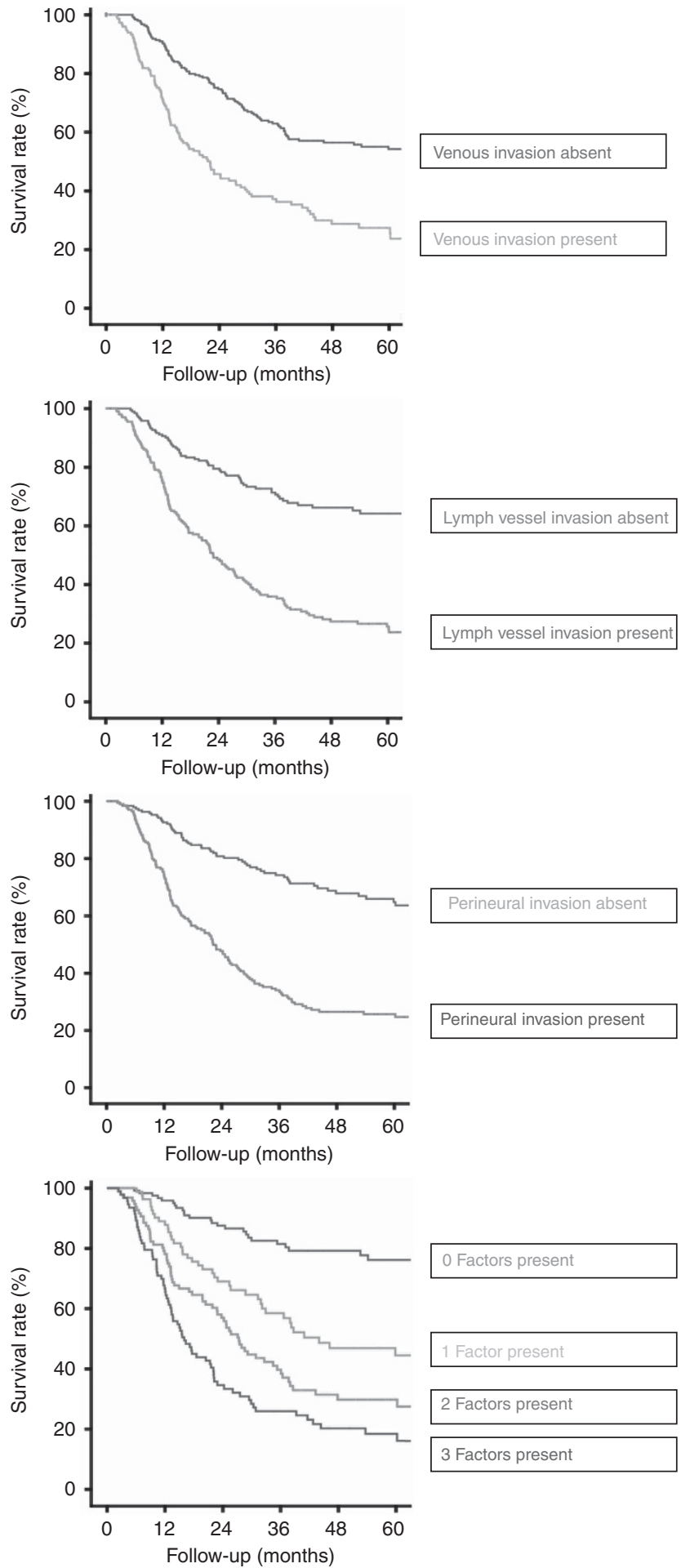

Figure 1. Overall survival for each individual factor and the impact of multiple factors.

unimodality surgical treatment. Other reports have suggested an incidence of PNI as high as $45 \%$ in squamous cell cancers of the oesophagus and $54 \%$ in all oesophageal subtypes (Torres et al, 1999; Chen et al, 2014) and LVI of up to 48\% (Sarbia et al, 1995) and VI of up to $56 \%$ (Torres et al, 1999). At our institution the presence or absence of these factors was recorded with only $1.2 \%$ of reports failing to comment on these factors. The findings from this study have indicated a much higher level of presence of each of these factors, which may have a significant bearing on predicting a
Table 3. Uni- and multivariate analysis of prognostic factors for disease-free survival in patients with cancer of the oesophagus or GOJ who underwent neoadjuvant chemoradiation therapy followed by a transthoracic oesophagectomy

\begin{tabular}{|c|c|c|c|}
\hline & $\begin{array}{c}\text { Median survival } \\
\text { (95\% confidence } \\
\text { interval) }\end{array}$ & $\begin{array}{c}P \text {-value } \\
\text { univariate }^{\mathrm{a}}\end{array}$ & $\begin{array}{c}P \text {-value } \\
\text { multivariate }\end{array}$ \\
\hline \multicolumn{4}{|l|}{ Age } \\
\hline $\begin{array}{l}<65 \\
\geqslant 65\end{array}$ & $\begin{array}{l}37.98(29.09-46.87) \\
40.90(15.20-66.60)\end{array}$ & 0.676 & - \\
\hline \multicolumn{4}{|l|}{ Sex } \\
\hline $\begin{array}{l}\text { Male } \\
\text { Female }\end{array}$ & $\begin{array}{l}97.31(57.8-136.83) \\
32.89(26.54-39.24)\end{array}$ & 0.005 & 0.006 \\
\hline \multicolumn{4}{|l|}{ Histology type } \\
\hline $\begin{array}{l}\text { Adeno } \\
\text { Squamous cell }\end{array}$ & $\begin{array}{l}35.29(27.22-43.35) \\
65.61(28.39-102.83)\end{array}$ & 0.054 & 0.030 \\
\hline \multicolumn{4}{|l|}{ Tumour location } \\
\hline $\begin{array}{l}\text { Mid oesophagus } \\
\text { Distal oesophagus } \\
\text { GOJ }\end{array}$ & $\begin{array}{l}98.10(35.12-161.09) \\
37.98(21.17-54.80) \\
34.43(24.32-44.54)\end{array}$ & 0.145 & - \\
\hline \multicolumn{4}{|l|}{ Radicality } \\
\hline $\begin{array}{l}\text { R0 } \\
\text { R1 }\end{array}$ & $\begin{array}{r}40.9(26.60-55.21) \\
12.62(11.86-13.38)\end{array}$ & 0.001 & 0.002 \\
\hline \multicolumn{4}{|c|}{ Post-treatment T stage (ypT) } \\
\hline $\begin{array}{l}\text { ypT0 } \\
\text { ypT1 } \\
\text { YpT2 } \\
\text { ypT3 } \\
\text { ypT4 }\end{array}$ & $\begin{array}{c}150.68(111.72-182.66) \\
97.31(77.91-116.72) \\
78.48(66.39-90.57) \\
28.55(24.01-33.09) \\
7.52(3.09-11.96)\end{array}$ & $<0.001$ & 0.150 \\
\hline \multicolumn{4}{|c|}{ Post-treatment $\mathrm{N}$ stage (ypN) } \\
\hline $\begin{array}{l}\text { ypN0 } \\
\text { ypN1 } \\
\text { ypN2 } \\
\text { ypN3 }\end{array}$ & $\begin{array}{c}170.84(72.27-269.41) \\
66.07(15.94-116.20) \\
24.25(17.03-31.46) \\
13.21(9.93-16.49)\end{array}$ & $<0.001$ & $<0.001$ \\
\hline \multicolumn{4}{|c|}{ The presence of VI, $\mathrm{LI}$ and PNI } \\
\hline $\begin{array}{l}\text { No presence } \\
\text { One factor present } \\
\text { Two factors present } \\
\text { Three factors present }\end{array}$ & $\begin{array}{c}170.84(69.94-272.75) \\
40.90(19.95-61.86) \\
27.11(22.76-31.45) \\
16.33(10.27-22.39)\end{array}$ & $<0.001$ & 0.007 \\
\hline $\begin{array}{l}\text { Abbreviations: } \mathrm{GOJ}=\mathrm{ga} \\
\text { perineural invasion; } \mathrm{RO}=\mathrm{r} \\
\text { behind; } \mathrm{VI}=\text { venous invas } \\
\text { a }{ }^{\text {Log-rank test. }}\end{array}$ & $\begin{array}{l}\text {-oesophageal junction; LI } \\
\text { oscopically radical resection } \\
\text { The bold entries are those }\end{array}$ & $\begin{array}{l}\text { mph vessel } \\
=\text { microscopi }\end{array}$ & $\begin{array}{l}\text { invasion; } \mathrm{PNI}= \\
\text { ically tumour left } \\
\text { ally significant. }\end{array}$ \\
\hline
\end{tabular}

patient's prognosis and may be due to the use of a formalised pathology pro forma. This study, however, has not differentiated between intra- and extramural invasions as a factor.

Presence of VI, LI and PNI in this study conveys similar prognostic outcomes to respective ' $\mathrm{N}$ ' staging with a single factor being approximately equivalent to $\mathrm{N} 1$, through to the presence of all three factors equating to a similar prognosis as N3. Although it would be beneficial to determine the significance of each of these factors and whether any have greater importance, separate sub-analysis in this study showed all three factors were independently related to survival, and thus all should be assessed. The suggestion of VI, PNI and LI as adverse prognostic factors has been well described in other cancers. Lymphovascular involvement has been found to correlate with TNM disease stage in breast, endometrial, gastric and colonic cancers (Royston and Jackson, 2009; Cornwell et al, 2011; Guntupalli et al, 2012; Li et al, 2015) and similarly PNI has been recorded as a poor prognostic factor in gastric, prostate, colonic and pancreatic cancers (Ozaki et al, 1999; Duraker et al, 2003; Beard et al, 2004; Law and Chu, 2004). The prognostic significance of VI remains unclear with a number of studies suggesting that it has independent prognostic value (Sarbia 
et al, 1995; Reynolds et al, 2010) although this may be cancer subtype specific (Tachezy et al, 2014), whilst others have found that VI does not have a prognostic impact (Khan et al, 2004; Waraich et al, 2011).

In conclusion, these findings suggest the presence of VI, LI and PNI after neoadjuvant therapy followed by oesophagectomy may have an important prognostic role. Their presence should be incorporated in a standardised pathology report as they provide additional information for identifying patients at high risk of disease recurrence who may be candidates for adjuvant therapies.

\section{CONFLICT OF INTEREST}

The authors declare no conflict of interest.

\section{REFERENCES}

Allum WH, Stenning SP, Bancewicz J, Clark PI, Langley RE (2009) Long-term results of a randomized trial of surgery with or without preoperative chemotherapy in esophageal cancer. J Clin Oncol 27: 5062-5067.

Arnold M, Soerjomataram I, Ferlay J, Forman D (2015) Global incidence of oesophageal cancer by histological subtype in 2012. Gut 64: 381-387.

Beard CJ, Chen MH, Cote K, Loffredo M, Renshaw AA, Hurwitz M, D'Amico AV (2004) Perineural invasion is associated with increased relapse after external beam radiotherapy for men with low-risk prostate cancer and may be a marker for occult, high-grade cancer. Int J Radiat Oncol Biol Phys 58: 19-24.

Bollschweiler E, Hölscher AH, Metzger R, Besch S, Mönig SP, Baldus SE, Drebber U (2011) Prognostic significance of a new grading system of lymph node morphology after neoadjuvant radiochemotherapy for esophageal cancer. Ann Thorac Surg 92: 2020-2027.

Chatterjee D, Katz MH, Rashid A, Wang H, Iuga AC, Varadhachary GR, Wolff RA, Lee JE, Pisters PW, Crane CH, Gomez HF, Abbruzzese JL, Fleming JB, Wang H (2012) Perineural and intraneural invasion in posttherapy pancreaticoduodenectomy specimens predicts poor prognosis in patients with pancreatic ductal adenocarcinoma. Am J Surg Pathol 36 : 409-417.

Chen J-W, Xie J-D, Ling Y-H, Li P, Yan S-M, Xi S-Y, Luo R-Z, Yun J-P, Xie D, Cai M-Y (2014) The prognostic effect of perineural invasion in esophageal squamous cell carcinoma. BMC Cancer 14: 313.

Cornwell LB, McMasters KM, Chagpar AB (2011) The impact of lymphovascular invasion on lymph node status in patients with breast cancer. Am Surg 77: 874-877.

Cunningham D, Allum WH, Stenning SP, Thompson JN, Van de Velde CJH, Nicolson M, Scarffe JH, Lofts FJ, Falk SJ, Iveson TJ, Smith DB, Langley RE, Verma M, Weeden S, Chua YJ. MAGIC Trial Participants (2006) Perioperative chemotherapy versus surgery alone for resectable gastroesophageal cancer. $N$ Engl J Med 355: 11-20.

Cunningham D, Starling N, Rao S, Iveson T, Nicolson M, Coxon F, Middleton G, Daniel F, Oates J, Norman AR (2008) Capecitabine and oxaliplatin for advanced esophagogastric cancer. $N$ Engl J Med 358: $36-46$.

D'Annoville T, D'Journo XB, Loundou A, Trousse D, Dahan L, Doddoli C, Seitz JF, Thomas PA (2013) Prognostic impact of the extracapsular lymph node involvement on disease-free survival according to the 7th edition of American Joint Committee on Cancer Staging System. Eur J Cardiothorac Surg 44: e207-e211, discussion e211.

Davies AR, Gossage JA, Zylstra J, Mattsson F, Lagergren J, Maisey N, Smyth EC, Cunningham D, Allum WH, Mason RC (2014) Tumor stage after neoadjuvant chemotherapy determines survival after surgery for adenocarcinoma of the esophagus and esophagogastric junction. J Clin Oncol 32: 2983-2990.

Duraker N, Sişman S, Can G (2003) The significance of perineural invasion as a prognostic factor in patients with gastric carcinoma. Surg Today $\mathbf{3 3}$ $95-100$.

Eguchi T, Nakanishi Y, Shimoda T, Iwasaki M, Igaki H, Tachimori Y, Kato H, Yamaguchi H, Saito D, Umemura S (2006) Histopathological criteria for additional treatment after endoscopic mucosal resection for esophageal cancer: analysis of 464 surgically resected cases. Mod Pathol 19: 475-480.

Griffin SM, Shaw IH, Dresner SM (2002) Early complications after Ivor Lewis subtotal esophagectomy with two-field lymphadenectomy: risk factors and management. J Am Coll Surg 194: 285-297.

Guntupalli SR, Zighelboim I, Kizer NT, Zhang Q, Powell MA, Thaker PH, Goodfellow PJ, Mutch DG (2012) Lymphovascular space invasion is an independent risk factor for nodal disease and poor outcomes in endometrioid endometrial cancer. Gynecol Oncol 124: 31-35.

Guo X-F, Mao T, Gu Z-T, Ji C-Y, Fang W-T, Chen W-H (2014) Clinical study on postoperative recurrence in patients with $\mathrm{pN} 0$ esophageal squamous cell carcinoma. J Cardiothorac Surg 9: 150.

Van Heijl M, van Lanschot JJB, Koppert LB, van Berge Henegouwen MI, Muller K, Steyerberg EW, van Dekken H, Wijnhoven BPL, Tilanus HW, Richel DJ, Busch ORC, Bartelsman JF, Koning CCE, Offerhaus GJ, van der Gaast A (2008) Neoadjuvant chemoradiation followed by surgery versus surgery alone for patients with adenocarcinoma or squamous cell carcinoma of the esophagus (CROSS). BMC Surg 8: 21.

Kelsen DP, Ginsberg R, Pajak TF, Sheahan DG, Gunderson L, Mortimer J, Estes N, Haller DG, Ajani J, Kocha W, Minsky BD, Roth JA (1998) Chemotherapy followed by surgery compared with surgery alone for localized esophageal cancer. N Engl J Med 339: 1979-1984.

Khan OA, Alexiou C, Soomro I, Duffy JP, Morgan WE, Beggs FD (2004) Pathological determinants of survival in node-negative oesophageal cancer. Br J Surg 91: 1586-1591.

Lagarde SM, Reitsma JB, Ten Kate FJW, Busch ORC, Obertop H, Zwinderman AH, Moons J, van Lanschot JJB, Lerut T (2008) Predicting individual survival after potentially curative esophagectomy for adenocarcinoma of the esophagus or gastroesophageal junction. Ann Surg 248: 1006-1013.

Langer R, Ott K, Feith M, Lordick F, Siewert J-R, Becker K (2009) Prognostic significance of histopathological tumor regression after neoadjuvant chemotherapy in esophageal adenocarcinomas. Mod Pathol 22: $1555-1563$.

Law WL, Chu KW (2004) Anterior resection for rectal cancer with mesorectal excision: a prospective evaluation of 622 patients. Ann Surg 240: $260-268$.

Li P, He H-Q, Zhu C-M, Ling Y-H, Hu W-M, Zhang X-K, Luo R-Z, Yun J-P, Xie D, Li Y-F, Cai M-Y (2015) The prognostic significance of lymphovascular invasion in patients with resectable gastric cancer: a large retrospective study from Southern China. BMC Cancer 15: 370.

Li S-H, Wang Z, Liu X-Y, Liu F-Y, Sun Z-Y, Xue H (2007) Lymph node micrometastasis: a predictor of early tumor relapse after complete resection of histologically node-negative esophageal cancer. Surg Today 37: 1047-1052.

Liebig C, Ayala G, Wilks JA, Berger DH, Albo D (2009) Perineural invasion in cancer: a review of the literature. Cancer 115: 3379-3391.

Mapstone N (2007) Dataset for the histopahtological reporting of oesophageal carcinoma. Standard No. G006, 2nd edn, The Royal College of Pathologists, London, UK.

Matsuyama J, Doki Y, Yasuda T, Miyata H, Fujiwara Y, Takiguchi S, Yamasaki M, Makari Y, Matsuura N, Mano M, Monden M (2007) The effect of neoadjuvant chemotherapy on lymph node micrometastases in squamous cell carcinomas of the thoracic esophagus. Surgery 141: $570-580$.

Ozaki H, Hiraoka T, Mizumoto R, Matsuno S, Matsumoto Y, Nakayama T, Tsunoda T, Suzuki T, Monden M, Saitoh Y, Yamauchi H, Ogata Y (1999) The prognostic significance of lymph node metastasis and intrapancreatic perineural invasion in pancreatic cancer after curative resection. Surg Today 29: 16-22.

Peyre CG, Hagen JA, DeMeester SR, Altorki NK, Ancona E, Griffin SM, Hölscher A, Lerut T, Law S, Rice TW, Ruol A, van Lanschot JJB, Wong J, DeMeester TR (2008) The number of lymph nodes removed predicts survival in esophageal cancer: an international study on the impact of extent of surgical resection. Ann Surg 248: 549-556.

Reynolds JV, Ravi N, Muldoon C, Larkin JO, Rowley S, O’Byrne K, Hollywood D, O’Toole D (2010) Differential pathologic variables and outcomes across the spectrum of adenocarcinoma of the esophagogastric junction. World J Surg 34: 2821-2829.

Royston D, Jackson DG (2009) Mechanisms of lymphatic metastasis in human colorectal adenocarcinoma. J Pathol 217: 608-619. 
Sant M, Aareleid T, Berrino F, Bielska Lasota M, Carli PM, Faivre J, Grosclaude P, Hédelin G, Matsuda T, Møller H, Möller T, Verdecchia A, Capocaccia R, Gatta G, Micheli A, Santaquilani M, Roazzi P, Lisi D (2003) EUROCARE-3: survival of cancer patients diagnosed 1990-94-results and commentary. Ann Oncol 14(Suppl 5): v61-v118.

Sarbia M, Porschen R, Borchard F, Horstmann O, Willers R, Gabbert HE (1995) Incidence and prognostic significance of vascular and neural invasion in squamous cell carcinomas of the esophagus. Int J Cancer 61: 333-336.

Sobin LH, Gospodarowicz MK, Wittekind C (eds) (2009) TNM Classification of Malignant Tumours, 7th edn. Wiley-Blackwell.

Medical Research Council Oesophageal Cancer Working Group (2002) Surgical resection with or without preoperative chemotherapy in oesophageal cancer: a randomised controlled trial. Lancet 359: 1727-1733.

Tachezy M, Tiebel A-K, Gebauer F, Kutup A, Tharun L, Pantel K, Izbicki JR, Vashist YK (2014) Prognostic impact of perineural, blood and lymph vessel invasion for esophageal cancer. Histol Histopathol 29 : 1467-1475.

Torres C, Turner JR, Wang HH, Richards W, Sugarbaker D, Shahsafaei A, Odze RD (1999) Pathologic prognostic factors in Barrett's associated adenocarcinoma: a follow-up study of 96 patients. Cancer 85: 520-528.

Waraich N, Rashid F, Jan A, Semararo D, Deb R, Leeder PC, Iftikhar SY (2011) Vascular invasion is not a risk factor in oesophageal cancer recurrence. Int J Surg 9: 237-240.

This work is published under the standard license to publish agreement. After 12 months the work will become freely available and the license terms will switch to a Creative Commons AttributionNonCommercial-Share Alike 4.0 Unported License. 